\title{
A 150-year record of phytoplankton community succession controlled by hydroclimatic variability in a tropical lake
}

\author{
Kweku Afrifa Yamoah ${ }^{1}$, Nolwenn Callac ${ }^{1}$, Ernest Chi Fru ${ }^{1}$, Barbara Wohlfarth ${ }^{1}$, Alan Wiech ${ }^{1}$, \\ Akkaneewut Chabangborn ${ }^{2}$, and Rienk H. Smittenberg ${ }^{1}$ \\ ${ }^{1}$ Department of Geological Sciences and Bolin Centre for Climate Research, Stockholm University, \\ 10691 Stockholm, Sweden \\ ${ }^{2}$ Departments of Geology, Faculty of Science, Chulalongkorn University, Bangkok, 10330, Thailand \\ Correspondence to: Kweku Afrifa Yamoah (kweku.yamoah@geo.su.se)
}

Received: 12 December 2015 - Published in Biogeosciences Discuss.: 18 January 2016

Revised: 1 June 2016 - Accepted: 9 June 2016 - Published: 11 July 2016

\begin{abstract}
Climate and human-induced environmental change promote biological regime shifts between alternate stable states, with implications for ecosystem resilience, function, and services. While these effects have been shown for present-day ecosystems, the long-term response of microbial communities has not been investigated in detail. This study assessed the decadal variations in phytoplankton communities in a ca. 150 year long sedimentary archive of Lake Nong Thale Prong (NTP), southern Thailand using a combination of bulk geochemical analysis, quantitative polymerase chain reaction (qPCR) and lipid biomarkers techniques including compound-specific hydrogen isotope analysis as a proxy for precipitation. Relatively drier and by inference warmer conditions from ca. 1857 to 1916 Common Era (CE) coincided with a dominance of the green algae Botryococcus braunii, indicating lower nutrient levels in the oxic lake surface waters, possibly related to lake water stratification. A change to higher silica ( $\mathrm{Si}$ ) input around 1916 CE was linked to increased rainfall and concurs with an abrupt takeover by diatom blooms lasting for 50 years. These were increasingly outcompeted by cyanobacteria from the 1970s onwards, most likely because of increased levels of anthropogenic phosphate and a reduction in rainfall. Our results showcase that the multi-proxy approach applied here provides an efficient way to track centennial-scale limnological, geochemical and microbial change, as influenced by hydroclimatic and anthropogenic forcing.
\end{abstract}

\section{Introduction}

Natural and anthropogenically induced climatic change is often cited as the main factor controlling ecosystem dynamics (Scheffer et al., 2001; Malmqvist et al., 2008; Woodward et al., 2010). The resulting environmental effects easily observed today in plant and animal communities (Scheffer et al., 2001) have been discussed as causing regime shifts (Folke et al., 2004) and/or introducing alternative ecosystem states (Dent et al., 2002). Changes in the ecosystem due to climate dynamics, particularly for microbial communities, would likely affect the capture and storage of $\mathrm{CO}_{2}$ (Zeglin et al., 2013). However, predicting the effects of changing climate on shifts in microbial community structures even on short-time scales is challenging (Lotter and Birks, 1997; Woodward et al., 2010). This is partially due to the difficulty of coupling micro-scale external and internal ecosystem variables to specific microbial communities over longer time scales. Consequently, most estimates are based on smallscale and short-term experimental data and on easily manipulated ecosystems such as soils (Landesman and Dighton, 2010; Cregger et al., 2012; Kuffner et al., 2012; Zeglin et al., 2013). Very little is therefore known about how natural microbial ecosystems respond to climatic changes over longer time scales and whether the associated feedbacks due to climate shifts promote regime shifts and alternative stable states. Moreover, the impact of external processes, such as weathering and runoff intensity, on carbon and nitrogen cycles still remain relatively unknown. 
Phytoplankton constitutes one of the most ecologically important groups of microorganisms in aquatic ecosystems (Yin et al., 2011) due to their vital position at the base of the food chain (Carpenter et al., 1987; Young et al., 2013). As photoautotrophs, their activities are directly coupled to climatic changes through $\mathrm{CO}_{2}$ drawdown, organic matter availability and oxygen production. Natural and/or human-induced disturbances may thus result in far-reaching consequences for the nutrient status of lakes, in which phytoplankton is the primary producer (Yin et al., 2011). For instance, the demise of the botryococcene lipid-producing green algae Botryococcus braunii was linked to early eutrophication in a Norwegian fjord (Smittenberg et al., 2005).

Studies have shown that phytoplankton communities are sensitive to environmental stressors (Woodward et al., 2010; Häder and Gao, 2015) where variations in phytoplankton community structure, abundance and function have been related to changes in lake trophic status (Ravasi et al., 2012; Hou et al., 2014). Accordingly, the emerging paradigm suggests that the structuring of phytoplankton communities, characterized by potential successional shifts in population dynamics, may serve as a tracer for the trophic status in lakes (Mackay et al., 2003; De Senerpont Domis et al., 2007). However, reconstructing the trophic status of lakes based on shifts in dominant phytoplankton communities over time are yet to be explored in detail. Also, the broader linkages between different microbial groups and their response to past environmental conditions are poorly understood. This is partly due to the lack of suitable proxies that can capture and distinguish between the diverse parameters impacting microbial ecosystem structure.

Lipid biomarkers specific for various types of microbes provide an important proxy of microbial ecosystem structure and have therefore been employed in the reconstruction of past ecosystems preserved in sedimentary records (Zimmerman and Canuel, 2000; Coolen et al., 2004; Smittenberg et al., 2005). Lipids are an integral part of the cell membranes of both prokaryotes and eukaryotes. They aid as structural support and as storage compounds within various microbial cells (Jungblut et al., 2009), and can be specific for certain groups or species. Moreover, lipid biomarkers can incorporate information of the chemical and physical environment in which they have formed via their relative abundance or isotopic composition. Because lipids are resistant to postmortem biodegradation, ecological variations through time can be reconstructed (Zimmerman and Canuel, 2000; Coolen et al., 2004; Smittenberg et al., 2005) by tracking their occurrence and abundance over longer time scales. Moreover, when coupled to hydroclimate variables such as hydrogen isotopes of leaf waxes $\left(\delta D_{\text {wax }}\right)$, a proxy for precipitation (e.g. Konecky et al., 2013; Niedermeyer et al., 2014), microbial lipids may help underpin the impact of past climates (wetter/drier) on microbial ecosystem changes (see Supplement).

Quantitative polymerase chain reactions (qPCR) of specific DNA of living organisms and well-preserved DNA in lake sediments are excellent tools to assess present and past microbial ecosystem structures (Coolen and Gibson, 2009; Ravasi et al., 2012; Hou et al., 2014). These analyses provide specific proof of recent and past biological processes by targeting specific microbial taxa and key genes involved in various metabolic pathways (Takai and Horikoshi, 2000; Hou et al., 2014).

Here we explore the novel combination of biolipid analysis, $\delta D_{\text {wax }}$, qPCR, bulk isotopes of carbon and nitrogen, and sedimentary geochemistry to reconstruct phytoplankton community dynamics over a 150-year history of Lake Nong Thale Prong (NTP), Southern Thailand. Together, these proxies allow unravelling how external forcing (hydroclimate and human impact) influences internal abiotic feedback processes, which in turn control phytoplankton regime shifts.

\section{Materials and methods}

\subsection{Study area, fieldwork, sediment sampling, and dating}

NTP $\left(17^{\circ} 11^{\prime} \mathrm{N}, 9^{\circ} 23^{\prime} \mathrm{E}\right)$ is a shallow (<4 m water depth), small $\left(\sim 210 \mathrm{~m}^{2}\right)$ sinkhole lake located on the Thai-Malay Peninsula in southern Thailand (Fig. 1) at $\sim 60 \mathrm{~m}$ above sea level (Snansieng et al., 1976) (see Supplement). Prior to coring, a preliminary assessment of NTP was conducted based on the catchment geology and topography, basin size and water depth. Sounding in different parts of the lake showed that the deepest part ( $\sim 3.7 \mathrm{~m}$ water depth) was in the northeast and that there was little variability in the distribution of sedimentary materials throughout the lake. Two sediment cores ( $\sim 74 \mathrm{~cm}$ length) were retrieved from the deepest part of the lake in January 2012 using an HTH gravity corer $(70 \mathrm{~mm}$ diameter, $1 \mathrm{~m}$ length). The sediment presented a strong sulfidic smell, suggesting anoxic conditions. Visually, the cores were lithologically similar. Therefore further analysis was performed on one core, while the other core was archived. The sediment core was sliced on-site into $1 \mathrm{~cm}$ sub-samples, packed in sterile plastics bags and chilled with ice. The samples were kept at temperature of about $4{ }^{\circ} \mathrm{C}$ during transportation from Thailand to Stockholm. Such temperatures have been shown to be low enough to inactivate and preserve whole tropical communities in sediments without the need for dramatic freezing because of a narrower temperature range of activity (e.g. Robador et al., 2016). After arrival at the Department of Geological Sciences, Stockholm University the samples were immediately frozen $\left(-18^{\circ} \mathrm{C}\right)$ until further analysis. The sampled sediment sequence was dated using ${ }^{210} \mathrm{~Pb}(46.51 \mathrm{keV})$ and ${ }^{226} \mathrm{Rn}(295.2 \mathrm{keV})$ on an EG\&G ORTEC $^{\circledR}$ co-axial low energy photo spectrometer (LEPS) fitted with a high-purity germanium crystal (see Supplement). 


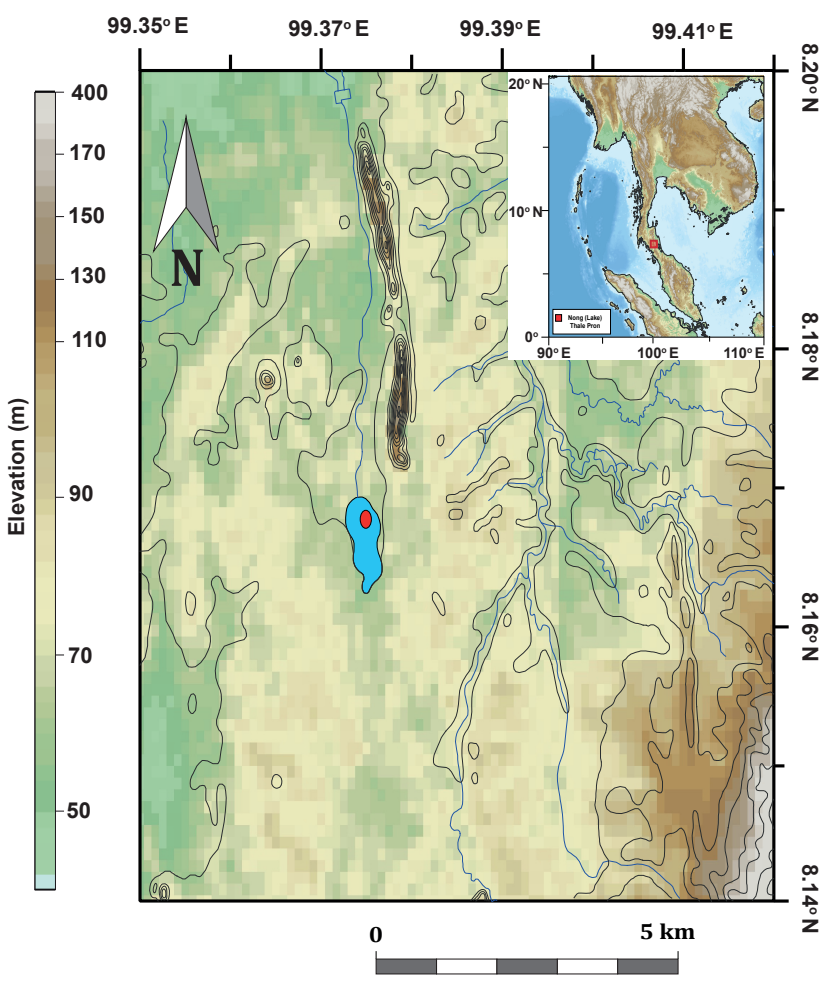

Figure 1. Location of the study area in southern Thailand and topography of Lake Nong Thale Prong (shaded blue). A red circle shows the coring site. For interpretation of the references to colour, the reader is referred to the web version of this article.

\subsection{Bulk biogeochemical analysis}

A total of 15 sub-samples were taken at different core depths for a low-resolution quantification of total organic carbon (TOC), total nitrogen (TN), and carbon and nitrogen isotopes $\left(\delta^{13} \mathrm{C}_{\text {bulk org }}\right.$ and $\left.\delta^{15} \mathrm{~N}_{\text {bulk org }}\right)$. Samples were freeze-dried and homogenised before analysis. For the stable isotope measurements, the samples were pre-treated with $\mathrm{HCl}$ to remove carbonate carbon before analysis on a Carlo Erba NC2500 elemental analyzer, coupled to a Finnigan MAT Delta + mass spectrometer. $\delta^{13} \mathrm{C}_{\text {bulk org }}$ and $\delta^{15} \mathrm{~N}_{\text {bulk org }}$ values are reported in parts per mille (\%o) relative to the Vienna PeeDee Belemnite (VPDB, for C) and standard air (for N), respectively, with an analytical error of $\pm 0.15 \%$ o. The working standards used for the analysis were: (1) acetanilide $\left(\delta^{13} \mathrm{C}=-27.07 \%\right.$; $\% \mathrm{C}=71.09 \% ; \delta^{15} \mathrm{~N}=1 \%$; $\left.\% \mathrm{~N}=10.36 \%\right)$ and (2) methionine $\left(\delta^{13} \mathrm{C}=-26.23 \%\right.$; \% $\mathrm{C}=40.25 \% ; \delta^{15} \mathrm{~N}=-2.24 \%$; $\% \mathrm{~N}=9.39 \%$ ). These standards were calibrated against standards from IAEA.

Relative estimates of the chemical composition of the sediments were obtained by elemental mapping using Environmental Scanning Electron Microscopy (FEI, Quanta FEG 650)-Electron Dispersive Spectroscopy (ESEM-EDS). An aliquot of the dried sediment was mounted on aluminium stubs with carbon tape and imaged at $10 \mathrm{kV}$ in low vacuum. Elemental analysis was conducted in low vacuum with EDS at $30 \mathrm{kV}$. Approximately 75 elemental maps distributed over 15 samples across the entire core were acquired with the AZtech software, at a horizontal field width of $2 \mathrm{~mm}, 512$ pixels and an average frame count of 5 with $100 \mu$ s pixel dwell time. The relative elemental abundance acquired was normalised to $100 \%$.

\subsection{Biomarker analysis}

Description of the biomarker analysis follows that of Chawchai et al. (2015) and Yamoah et al. (2016). Freezedried and powdered samples were extracted three times with a mixture of dichloromethane and methanol (DCM-MeOH, $9: 1, v / v$ ) to obtain a combined total lipid extract (TLE), using a microwave system (MILESTONE Ultra Wave Single Chamber Microwave Digestion System) fitted with a LABTECH smart H150-1000 Water Chiller. The TLE from the sediments was dried in a vacuum concentrator (Scanvac MaxiVac Beta, Labogene ApS, Denmark) before being redissolved in DCM and then adsorbed onto a small amount of silica gel. This was evaporated on a warm plate, under a very gentle stream of nitrogen gas, and placed on top of $15 \mathrm{~g}$ silica gel (deactivated with $5 \%$ (wt.) $\mathrm{H}_{2} \mathrm{O}$ ) in $6 \mathrm{~mL}$ glass SPE tubes. Hydrocarbon (FI), ketone (F2) and polar (F3) fractions were recovered with pure hexane, a hexane and DCM mixture $(1: 1)$ and $\mathrm{DCM}-\mathrm{MeOH}(1: 1)$, respectively. F2 and F3 samples were stored in the freezer for later use. The F1 fraction was analysed on a Shimadzu GCMSQP2010 Ultra gas chromatography-mass spectrometer (GCMS), equipped with an AOC- 20i auto sampler and a splitsplitless injector operated in splitless mode. A Zebron ZB5HT Inferno GC column $(30 \mathrm{~m} \times 0.25 \mathrm{~mm} \times 0.25 \mu \mathrm{m})$ was used for separation.

The GC oven temperature was programmed from 60 to $180^{\circ} \mathrm{C}$ at a ramp of $20^{\circ} \mathrm{C} \mathrm{min}^{-1}$ followed by a ramp of $4^{\circ} \mathrm{C} \mathrm{min}^{-1}$ until $320^{\circ} \mathrm{C}$ where it was held for $20 \mathrm{~min}$. MS operating conditions were set to an ion source temperature of $20{ }^{\circ} \mathrm{C}$ and $70 \mathrm{eV}$ ionisation energy. Spectra were collected using GC solution Workstation software (v2). $n$-alkanes, $\mathrm{C}_{25}$ highly branched isoprenoids (HBIs) and botryococcene compounds were identified by retention times and comparison against mass spectra from the literature. Quantification of the $n$-alkanes, $\mathrm{C}_{25} \mathrm{HBIs}$ and botryococcene compounds was done with an external standard consisting of a mixture of $\mathrm{C}_{20-40} n$-alkanes of known concentration. Specifics on the mass spectra and retention times of the $n$-alkanes, HBIs and Botryococcenes, including chromatograms as reference, are included in Supplement (Figs. S1-S6).

\section{$2.4 \delta D$ analysis of leaf waxes}

The F1 fraction was further separated into three fractions (F1a, F1b, and F1c) over a pipette column filled with $10 \%$ 
$\mathrm{AgNO}_{3}$-coated silica gel. F1a, which comprises $n$-alkanes, was eluted with hexane; F1b, made up of a few unidentified compounds, was eluted with hexane-DCM $(1: 1)$; and F1c consisting of HBIs and botryococcenes, was eluted with DCM-Acetone $(9: 1)$. F1b and F1c were also stored in the freezer for further analysis. F1a was analysed by gas chromatography-isotope ratio monitoring-mass spectrometry (GC-IRMS) using a Thermo Finnigan Delta V Plus mass spectrometer interfaced with a Thermo Trace GC 2000 using a GC Isolink II and Conflo IV system. Helium was used as a carrier gas at constant flow mode. A detailed description of the GC-IRMS program is described in Chawchai et al. (2015). Instrumental performance and calibration of the reference gas $\left(\mathrm{H}_{2}\right)$ was achieved by running a standard mixture of $n$-alkanes with a known isotopic composition (reference mixture A4, provided by Arndt Schimmelmann, Indiana University, USA) several times daily. All analyses performed follow that of Sessions et al. (1999, 2001). Results are reported as the weighted mean of triplicate measurements with an average standard deviation of both standards and samples around 4\%o (see Supplement).

\subsection{DNA extraction and qPCR}

Freeze-dried samples were selected according to initial biomarker screening results, in order to estimate the abundance of different groups of organisms related to: (1) the Prokarya, Archaea and bacteria, cyanobacteria, and microorganisms involved in anaerobic methane cycling (quantification of the mcrA gene, e.g., Hallam et al., 2003, 2004), (2) Eukarya, diatoms, and Botryococcus sp. The samples were analysed in order to specifically reflect the sample conditions used for the biomarker analysis. Freeze-drying was not expected to introduce significant biases, but it enhances cell breakage and the release of intracellular DNA, following the freeze thaw method of DNA extraction (e.g. Tsai and Olson, 1991). This is especially useful for soil and sediment samples (e.g. Tsai and Olson, 1991). Around $0.2 \mathrm{~g}$ (from 0.17 to $0.26 \mathrm{~g}$ ) of freeze-dried sediment was extracted for DNA, using the MoBio PowerSoil ${ }^{\circledR}$ DNA kit (Carlsbad, CA), following the manufacturer's instructions. About $500 \mu \mathrm{L}$ of sterile PBS 1X was also added to PowerSoil ${ }^{\circledR}$ Bead tube in order to enhance cell lysis efficiency.

The qPCR amplifications were conducted in 96 well qPCR plates in a CFX96 Touch $^{\mathrm{TM}}$ Real-Time PCR Detection System Instrument (C1000 Touch $^{\mathrm{TM}}$ Thermal, Cycler, Bio-Rad) and its software. The reactions consisted of a final volume of $25 \mu \mathrm{L}$, using the SsoAdvancedTM Universal SYBR ${ }^{\circledR}$ Green Supermix (Bio-Rad) following the manufacturer's recommendations. Reactions run in 35 cycles contained $5 \mu \mathrm{L}$ of DNA template and specific primer sets at their appropriate concentrations and annealing temperatures (see Supplement).

Standard curves were calibrated using 10 -fold serial dilutions from pure cultures of each representative target group
(Supplement). The qPCR detection of 16S rRNA genes, 18S rRNA genes in all of the samples and in 10-fold serial dilutions used to construct the standard curves was run in triplicates. For each qPCR, several negative controls were performed in order to check for laboratory contamination. The efficiencies of the qPCR analyses was up to $90 \%$ with a correlation to the standard calibration curve of up to $R^{2}=0.996$ (see Supplement).

A total of 16S rDNA and 18S rDNA gene copy numbers per $g$ of sediment were calculated from the triplicate average of each sample as described by Sylvan et al. (2013). Overall Prokaryotic cell abundance per gram of sediment was estimated by taking into account the average of the $16 \mathrm{~S}$ rRNA gene per cell equivalent to 1.86 for Archaea, 4.1 for bacteria (Lee et al., 2009) as previously used by Sylvan et al. (2013) and 2.18 for cyanobacteria (after calculation of the average using the data from Schirrmeister et al., 2012). Due to lack of references from lake sediments, one copy per cell of the $m c r A$ gene was used to quantify the population of organisms involved in anaerobic methane cycling.

The raw data of eukarya, diatoms, and Botryococcus sp. were not further quantified into copy numbers per g sediment, for two reasons: (1) there is high variability in $18 \mathrm{~S}$ rRNA gene copies per cell within the eukarya and diatoms (i.e. from 3 to more than 25000 copies per cell in the plants, Prokopowich et al., 2003; Zhu et al., 2005) and between 61 to 36896 for the diatoms (Godhe et al., 2008); (2) the paucity of information related to the number of $18 \mathrm{~S}$ rRNA gene copy number in the Botryococcus sp. genome. Therefore, the results reported here are indicative from the universal eukarya primer and should be considered as relative abundance of the total eukarya due to the tendency of not detecting all eukaryotic groups. Yet, the data are still useful to depict trends in the sediment record (see Supplement for limitations of qPCR methods).

\section{Results}

The ${ }^{210} \mathrm{~Pb}$ activity shows an exponential decay curve with depth, i.e. it shows a decreasing linear trend when plotted on

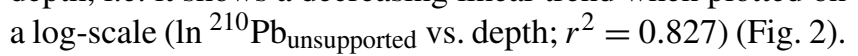
The profile indicates minimal sediment bioturbation and is used to calculate an average sedimentation rate of about $4.7 \mathrm{~mm} \mathrm{yr}^{-1}$.

Biogeochemical and biolipid screening of the sediment core, discussed further below, demarcates three distinct periods: ca. 2010-1969 CE, ca. 1969-1916 CE and ca. 1916$1857 \mathrm{CE}$. The sedimentary deposits are highly organic with TOC contents between 30 and $40 \%$. TOC gradually increases from ca. 1857 to $1870 \mathrm{CE}$ and then shows a decrease from ca. 1870 to 2008 CE (Fig. 3a). From ca. 1857 to $1970 \mathrm{CE}$ both the $\delta^{13} \mathrm{C}_{\text {bulk org (Fig. 3b) and TN (Fig. 3c) }}$ show a gradually increasing trend while $\delta^{15} \mathrm{~N}_{\text {org }}$ values rise steadily between ca. 1857 and $1969 \mathrm{CE}$ and then decreases 

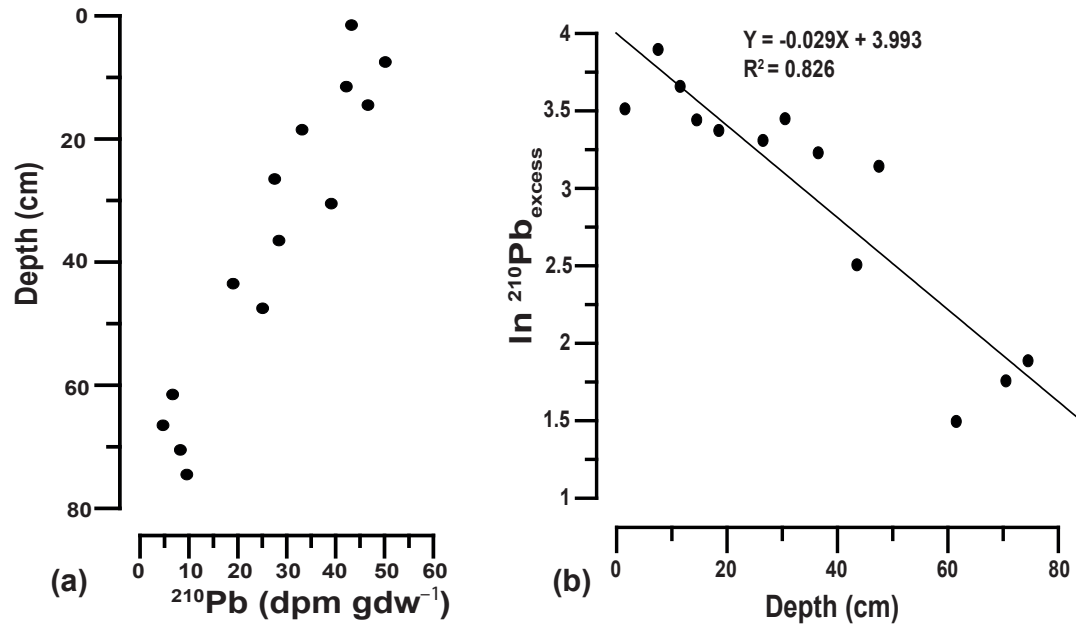

Figure 2. Variations in ${ }^{210} \mathrm{~Pb}$ down the sediment core, (a) Depth profile of total ${ }^{210} \mathrm{~Pb}$ activity downcore and (b) Correlation between depth and $\ln { }^{210} \mathrm{~Pb}_{\text {excess }}$.

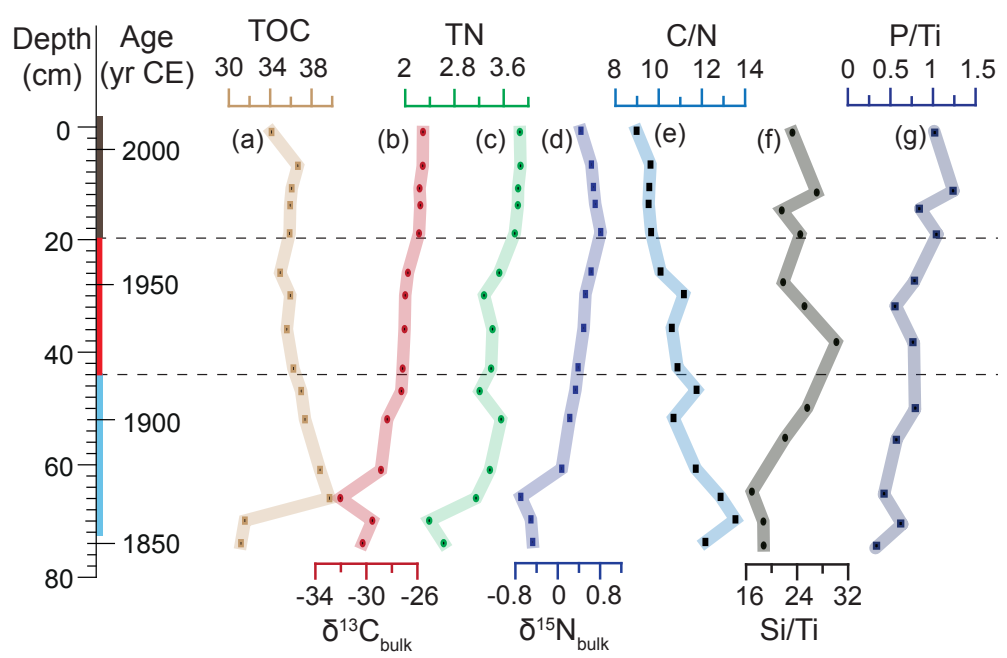

Figure 3. Geochemical data from Lake Nong Thale Pron (NTP) plotted against depth and age (a) TOC (\%), (b) $\delta^{13} \mathrm{C}_{\mathrm{bulk}}$ org, (c) $\mathrm{TN}(\%)$, (d) $\delta^{15} \mathrm{~N}_{\text {bulk org }}$, (e) C / N, (f) $\mathrm{Si} / \mathrm{Ti}$ and (g) P / Ti. The dashed lines represent the transition between the different units I, II, and III.

from ca. 1970 to $2010 \mathrm{CE}$ (Fig. 3d). The $\mathrm{C} / \mathrm{N}$ ratio, on the other hand, decreases gradually from the bottom to the top of the sediment core (Fig. 3e). Si / Ti ratio, a marker of silicon input into the lake from terrestrial sources, shows an increase between ca. 1916 and 1969 CE (Fig. 3f and g). Scanned photos using ESEM show higher abundances and diversity of diatoms between ca. 1916 and 1969 CE (see Supplement; Fig. S6). The P / Ti ratio, which can be used as a proxy for trophic conditions in lakes (Kirilova et al., 2011), show an increase from ca. 1970 to 2010 CE (Fig. 3g).

Biomarkers and qPCR analysis targeting cyanobacteria, diatoms and botryococcus exhibited similar trends, except ca. 1970-2010 CE where botryococcenes were not detected although the qPCR analysis detected the presence of Botryococcus sp. (Fig. 4) (see supplement for detailed qPCR re- sults). The botryococcene lipid concentrations show an increase between ca. 1857 and 1916 CE (Fig. 4a), followed by a decreasing trend from ca. 1916 to $2010 \mathrm{CE}$. The qPCR data set also shows an increase in Botryococcus sp. abundances from ca. 1857 to $1916 \mathrm{CE}$, a decrease from ca. 1916 to 1969 CE (Fig. 4b), but then again an increase from ca. 1970 to 2010 CE. The HBIs exhibit minimum levels until 1916, after which they show much higher abundance from ca. 1916 to $1969 \mathrm{CE}$, similar to the diatom abundance as detected by qPCR (Fig. 4c and d), and as seen by ESEM. After 1970 they decrease gradually. The $\mathrm{C}_{17} n$-alkanes concentrations show a close resemblance to the Cyanobacteria sp. detected by qPCR, with rising concentrations and abundances between ca. 1970 and 2010 CE (Fig. 4e and f). The hydrogen isotopic composition of leaf waxes $\left(\delta D_{\text {wax }}\right.$; weighted mean of $\delta D$ 


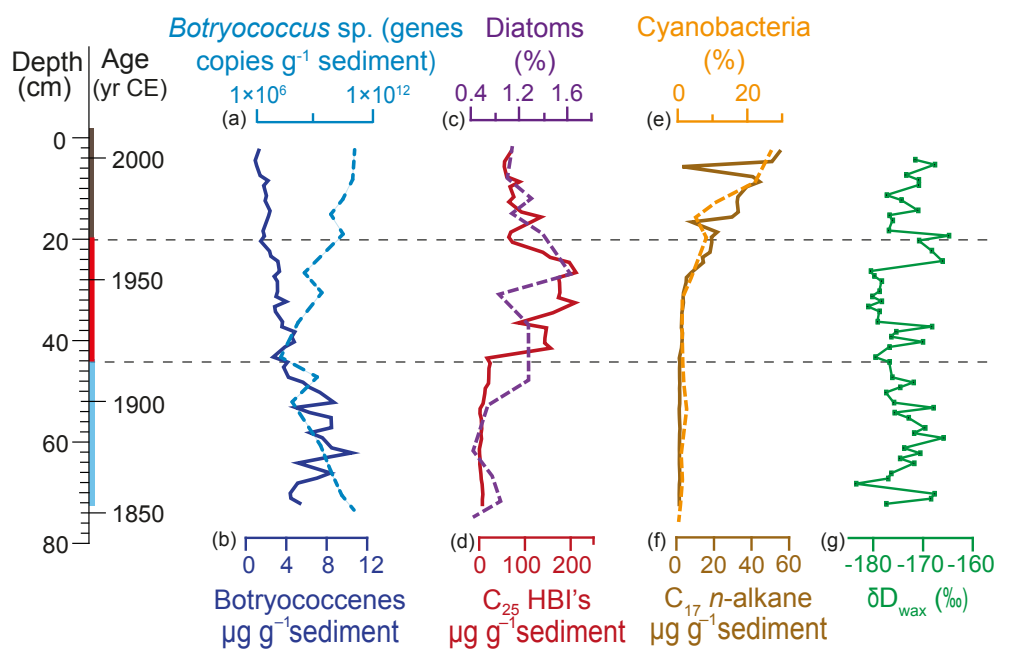

Figure 4. Depth and age profiles of: (a) Botryococcus sp. (18s rRNA genes copies $\mathrm{g}^{-1}$ sediment) (blue dashed), (b) botryococcenes, a proxy for Botryococcus braunii (B race) (blue solid), (c) diatoms (\%) (purple dashed), (d) $\mathrm{C}_{25}$ Highly branched Isoprenoid (HBIs), a proxy for diatoms (red solid), (e) cyanobacteria (\%) (mustard dashed), (f) $\mathrm{C}_{17} n$-alkane, a proxy for cyanobacteria (brown solid) and (g) $\delta D$ values of $\mathrm{C}_{27-29-31} n$-alkanes $\left(\delta D_{\mathrm{wax}}\right)$, a proxy for rainfall amount (green). The black dashed lines represent the transitions between the different units. For interpretation of the references to colour, the reader is referred to the web version of this article.

$\mathrm{C}_{27-31} n$-alkanes) shows a long-term oscillation over the entire 150-year record (Fig. 4g). $\delta D_{\text {wax }}$ values have been used as a proxy for rainfall intensity such that lower and higher values indicate an increase and decrease in rainfall intensity, respectively (e.g., Konecky et al., 2013; Niedermeyer et al., 2014). Reconstructed hydroclimatic conditions for southern Thailand over the last 150 years based on $\delta D_{\text {wax }}$ values show a relatively drier period from ca. 1857 to $1916 \mathrm{CE}$ and ca. 1970-2010 CE and relatively wetter conditions from ca. 1916 to 1969 CE.

\section{Discussion}

The bulk geochemical trends (Fig. 3) indicate that multiple processes control the organic matter $(\mathrm{OM})$ input into Lake NTP. Decreasing C / N ratios with TOC contents of approximately $30 \%$ from the bottom to the top of the core suggests organic matter diagenesis, which indicates an aquatic dominated system (Fig. 3a and b). The observed decreasing trend of the $\mathrm{C} / \mathrm{N}$ ratio, as well as increasing $\delta^{13} \mathrm{C}_{\text {org }}$ values, may be explained by a preferential (anoxic) mineralisation of nitrogen-rich OM, leading to residual OM with a higher $\mathrm{C} / \mathrm{N}$ ratio (Emerson and Hedges, 2003). This explanation would be consistent with the long-term diagenetic OM transformation (Sun et al., 2004). However, successional deposition of different phytoplankton communities, botryococcus (ca. 1857-1916), diatoms (ca. 1916-1969) and cyanobacteria (ca. 1970-2010), with different $\mathrm{C} / \mathrm{N}$ ratios, $\delta^{13} \mathrm{C}_{\text {org }}$, and $\delta^{15} \mathrm{~N}_{\text {org }}$ can also influence the bulk profiles.

An alternate interpretation of the increasing $\delta^{13} \mathrm{C}_{\text {org }}$ values from the bottom to the top of the core lies in a succes- sional shift of the trophic status of the lake (Brenner et al., 2000; Meyers and Teranes, 2001). Increasing nutrient levels promote primary productivity, thereby depleting the amount of dissolved inorganic carbon. This could lead to lower net fractionation against ${ }^{13} \mathrm{C}$ by the phytoplankton during photosynthesis, thereby increasing the $\delta^{13} \mathrm{C}_{\text {org }}$ values (Meyers and Teranes, 2001).

Observed variations of dominant phytoplankton community over time can be explained best by changes in the trophic level of the lake. The period from ca. 1857 to 1916 CE is marked by significant increases in both Botryococcus sp. abundance (Fig. 4a) and botryococcene lipids (Fig. 4b), which also corresponds with slightly lower precipitation (Fig. 4g). Botryococcus braunii has been suggested to thrive in relatively oligotrophic conditions (Souza et al., 2008) and can, therefore, be used as a proxy for such conditions within the oxygenated epilimnion (Waldmann et al., 2014). Although the highly organic sediment may suggest a productive lake, at variance with oligotrophic lake water conditions, we argue that the final TOC content in lake sediments, especially in the tropics, is more determined by OM preservation than by the incoming flux. In the tropics, the mean air temperature (MAT) is a direct result of incoming solar radiation, and the relationship between the MAT and the amount of rainfall are typically inversely proportional (Imboden and Wüest, 1995; Boehrer and Schultze, 2008). Dry, cloudless and warmer conditions lead to stronger stratification in freshwater lakes (Imboden and Wüest, 1995). We hypothesise that a long-term decrease in rainfall and slightly higher temperatures would result in a thermal stratification of the lake. Under stratified conditions reformed nutrients would remain in the anoxic hypolimnion. As a result, the sur- 
face water remained relatively oligotrophic enabling Botryococcus braunii to thrive, whereas the bottom of the lake was characterized by bacterial breakdown of organic N. This argument is supported by increasing $\delta^{15} \mathrm{~N}_{\mathrm{org}}$ values from ca. 1857 to $1916 \mathrm{CE}$, which suggests extensive denitrification in the lake sediment, as denitrification typically leads to more depleted $\delta^{15} \mathrm{~N}$ values in the residual organic matter (Wada, 1980).

A stark difference in the dominant phytoplankton community is observed from ca. 1916 to 1969 CE. This period is marked by significant decrease in Botryococcus sp. gene abundance (Fig. 4a) and botryococcene lipid concentrations (Fig. 4b) while diatom abundance (Fig. 4c) and $\mathrm{C}_{25}$ HBIs concentrations (Fig. 4d), which is a useful indicator of diatom-derived OM inputs to sediments (McKirdya et al., 2013) increases. More directly, we observed a marked increase in diatom diversity on the ESEM image scans of the sediments (Supplement; Fig. S6). Diatoms dominate phytoplankton communities as long as there is abundant silica irrespective of changes in environmental conditions and nutrient levels (Egge and Aksnes, 1992). Interestingly, the increase in diatom markers (Fig. 4c and d) coincides with an increase in reconstructed rainfall intensity (Fig. $4 \mathrm{~g}$ ). Moreover, the increase in $\mathrm{Si} / \mathrm{Ti}$ ratios (Fig. 3f), a run-off signal (Murphy et al., 2000), coincides with high diatom blooms, in particular between ca. 1916 and 1969 CE. Since Ti is a highly immobile element, weathering and transportation of $\mathrm{Si}$ is not accompanied by significant Ti delivery to aquatic basins. Therefore, the $\mathrm{Si} / \mathrm{Ti}$ ratio can serve as a proxy for nutrient dynamics linked to hydrological changes (e.g. Cartapanis et al., 2014) and as an indicator for enhanced diatom production in lakes (Wennrich et al., 2014). Altogether, it appears that the wetter conditions between ca. 1916 and 1969 CE increased catchment runoff into the lake, leading to elevated nutrient and silicate mineral flux to the lake water (e.g. Paerl and Fulton III, 2006). In line with the argument above, it is also well possible that an increase in precipitation was accompanied by cooler temperatures, which then led to a decrease in thermal stratification and an increase in mixing between the epilimnion and hypolimnion, making reformed nutrients from the bottom waters available at the lake water surface.

After ca. 1969 CE, the phytoplankton community structure changed again, with a diminishing role for diatoms as evidenced by lower concentrations of $\mathrm{C}_{25}$ HBIs (Fig. 4c) and the start of a marked increase in cyanobacteria gene numbers (Fig. 4e) and $\mathrm{C}_{17} n$-alkane concentrations (Fig. 4f). $\mathrm{C}_{17} n$-alkanes are recognised biomarkers of aquatic algae and photosynthetic bacteria such as cyanobacteria (Meyers, 2003). Indeed, cyanobacteria gene numbers relative to bacteria quantification based on the qPCR data covary strongly with $\mathrm{C}_{17} n$-alkane concentration, which indicates that the $\mathrm{C}_{17} n$-alkanes were likely produced by cyanobacteria. Additionally, the decreasing $\delta^{15} \mathrm{~N}_{\text {bulk org values during this period }}$ (Fig. 3d) also suggest nitrogen fixation, a process strongly associated with cyanobacteria blooms (Vahtera et al., 2007).
The most recent period (ca. 1969-2010 CE) is also characterized by somewhat lower rainfall amounts (Fig. 4g). The amount of $\mathrm{Si}$ indeed decreased, and diatoms became less abundant, allowing non-diatomaceous phytoplankton not dependent on Si to take over (Egge and Aksnes, 1992).

The number of botryococcus genes increased again (Fig. 4a). However, this was not accompanied by the production of botryococcene lipids. This mismatch can be the result of the primer used for the quantification of Botryococcus braunii not being specific enough. Botryococcus braunii are classified into three races: A, B, and L, and it is only the B race that produces botryococcenes (Eroglu et al., 2011), whereas the $\mathrm{A}$ and $\mathrm{L}$ races produce long-chain alkadienes and lycopadienes, respectively (Metzger and Largeau, 2005). A change in race thus may explain the disappearance of botryococcenes from the upper part of the sediment record. Since the qPCR primers for botryococcus were not specific enough, it is also possible that it picked up closely related green algae that took over the ecological niche of $\mathrm{B}$. Braunii under different trophic conditions. The absence of longchain alkadienes and lycopadienes in the upper sediment layers supports this argument and indicate that conditions had indeed become unfavourable to $B$. Braunii, in a similar way as described by Smittenberg et al. (2005).

Phosphorus bioavailability is one of the most important factors limiting aquatic cyanobacteria blooms (Paerl and Fulton III, 2006; Paerl and Valerie, 2012), and the shift to cyanobacterial prevalence thus suggests eutrophic phosphorous-rich conditions, instead of the oligotrophic-like conditions that occurred a century earlier under otherwise similar climatic conditions. Indeed, higher levels of phosphorus were detected in the upper part of the sediment (Fig. 3g). The source of the elevated phosphorus is unclear but has likely resulted from human activities. Under a land development program in the 1990s, more than $20 \%$ of Thailand's 56000 villages were located in forest reserves (Gray, 1991; Puri, 2006), which allowed the expansion of land encroachment and agricultural activities. For instance, southern Thailand has seen an increase in the cultivation of rubber trees on small farms at rates above $7 \% \mathrm{yr}^{-1}$ (Leturque and Swiggings, 2011). The use of fertilizers during farming activities, untreated wastewater effluents and the use of detergents are likely sources of the elevated phosphorus inputs into the lake (Litke, 1999; Chislock et al., 2013). These accelerated the eutrophic state of the lake beyond the natural rate of nutrient enrichment, which takes centuries to achieve (Litke, 1999).

According to our analysis, photosynthetic primary production is at the base of internal organic matter production in the lake. However, changes in precipitation and anthropogenic nutrient input have produced fluctuations in dominant primary producer communities over the last 150 years, from botryococcene lipid-producing algae to diatoms to a dominance of cyanobacteria. Overall, we suggest that NTP is sensitive to environmental stressors and that multiple processes discussed above control the OM input and carbon storage. 
The bulk geochemical analysis was clearly inadequate to disentangle the processes that have been controlling the limnological, ecological and microbial dynamics in NTP. Instead, the combination of bulk geochemistry, lipid biomarkers, and molecular DNA analysis could appropriately constrain many of these processes.

\section{Summary and conclusion}

Validation of paleoenvironmental and paleoclimatic proxies is necessary to constrain geochemical patterns through time. The coupled lipid biomarker and qPCR data allowed different microbial groups in the lake sediments to be distinguished and quantified, leading to the identification of meaningful biological relationships between the phytoplankton community structure response to either anthropogenic or natural environmental changes over the last 150 years.

Our results show that between ca. 1857 and 1916 CE, relatively drier climate in southern Thailand coincided with relatively oligotrophic surface water conditions in Lake NTP, which allowed Botryococcus braunii species to bloom. From ca. 1916 to $1969 \mathrm{CE}$, an increase in precipitation resulted in higher Si input into the lake, which led to a rapid takeover by diatoms as primary producers. Since the 1970s, many aspects of the initial limnic state returned upon drier conditions, except that anthropogenic impact led to an increase in phosphorus thereby allowing cyanobacteria to become a major contributor to primary productivity. Although the qPCR method did again detect genetic evidence for the presence of Botryococcus sp. over the last decades, the specific lipid biomarkers for Botryococcus sp. were not found anymore, which can be due to limitations of either proxy.

We conclude that the combination of geochemical and lipid biomarker proxies together with qPCR analyses is a useful approach that has the potential to assist in tracking the effects of changing climate on primary producers and also to assess these effects on the carbon cycle. This multi-proxy approach may help refine the knowledge about the use and shortcomings of the different proxies, which is critical for their interpretation especially when used on a more standalone basis.

Author contributions. This study was conceived and led by K. A. Yamoah, E. Chi Fru and R. H. Smittenberg. K. A. Yamoah, N. Callac, A. Wiech and A. Chabangborn carried out laboratory analyses. K. A. Yamoah, N. Callac, E. Chi Fru, B. Wohlfarth and R. H. Smittenberg wrote the manuscript. All authors discussed the results and their implications and commented on the manuscript as it progressed.

Acknowledgements. This work was supported by Swedish Research Council (VR) research grants 621-2008-2855, 3482008-6071 and 621-2011-4916 to Barbara Wohlfarth and Rienk
Smittenberg. Additional support came from the European Research Council (ERC) grant number 336092 to Ernest Chi Fru. We wish to thank Sherilyn Fritz, Wichuratree Klubseang, Sudo Inthonkaew, Minna Väliranta and Sakonvan Chawchai for sampling assistance; Jayne Rattray, Anna Hägglund, and Christoffer Hemmingsson for laboratory assistance; Alfred Burian for providing some eukarial strains; Anna Neubeck for providing the methanogen strain; and Frederik Schenk for assisting with observational precipitation data.

Edited by: N. Ohkouchi

Reviewed by: two anonymous referees

\section{References}

Boehrer, B. and Schultze, M.: Stratification of lakes, Rev. Geophys., 46, RG2005, doi:10.1029/2006RG000210, 2008.

Brenner, M., Whitmore, T. J., Lasi, M. A., Cable, J. E., and Cable, P. H.: A multi-proxy trophic state reconstruction for shallow Orange Lake, Florida, USA: possible influence of macrophytes on limnetic nutrient concentrations, J. Paleolimnol., 21, 215-233, 2000.

Carpenter, S. R., Kitchell, J. F., Hodgson, J. R., Cochran, P. A., Elser, J. J., Elser, M. M., Lodge, D. M., Kretchmer, D., He, X., and von Ende, C. N.: Regulation of lake primary productivity by food web structure, Ecology, 68, 1863-1876, 1987.

Cartapanis, O., Tachikawa, K., Romero, O. E., and Bard, E.: Persistent millennial-scale link between Greenland climate and northern Pacific Oxygen Minimum Zone under interglacial conditions, Clim. Past, 10, 405-418, doi:10.5194/cp-10-405-2014, 2014.

Chawchai, S., Yamoah, K. A., Smittenberg, R. H., Kurkela, J., Väliranta, M., Chabangborn, A., Blaauw, M., Fritz, S. C., Reimer, P. J., and Wohlfarth, B.: Lake Kumphawapi revisited - The complex climatic and environmental record of a tropical wetland in NE Thailand, The Holocene, 26, 614-626, 2016.

Chislock, M. F., Doster, E., Zitomer, R. A., and Wilson, A.: Eutrophication: causes, consequences, and controls in aquatic ecosystems, Nat. Edu. Knowledge, 4, 10 pp., 2013.

Coolen, M. J. L. and Gibson, J. A. E.: Ancient DNA in lake sediment records, Pages News, 17, 104-106, 2009.

Coolen, M. J. L., Muyzer, G., Rijpstra, W. I. C., Schouten, S., Volkman, J. K., and Sinninghe Damste, J. S.: Combined DNA and lipid analyses of sediments reveal changes in Holocene haptophyte and diatom populations in an Antarctic lake, Earth Planet Sc. Lett., 223, 225-239, 2004.

Cregger, M. A., Schadt, C. W., McDowell, N. G., Pockman, W. T. and Classen, A. T.: Response of the soil microbial community to changes in precipitation in a semiarid ecosystem, Appl. Environ. Microbiol., 78, 8587-8594, 2012.

De Senerpont Domis, L. N., Mooij, W. M., and Huisman, J.: Climate-induced shifts in an experimental phytoplankton community: a mechanistic approach, Hydrobiologia, 584, 403-413, 2007.

Dent, C. L., Cummings, G. S., and Carpenter, S. R.: Multiple states in river and lake ecosystems, Phil. Trans. R. Soc. B., 357, 635645, 2002.

Egge, J. K. and Aksnes, D. L.: Silicate as regulating nutrient in phytoplankton competition, Mar. Ecol. Prog.-Ser., 83, 281-289, 1992. 
Emerson, S. and Hedges, J.: Sediment diagenesis and benthic flux, Treatise on Geochem, 6, 293-319, 2003.

Eroglu, E., Okada, S., and Melis, A.: Hydrocarbon productivities in different Botryococcus strains: comparative methods in product quantification, J. Appl. Phycol., 23, 763-775, 2011.

Folke, C., Carpenter, S., Walker, B., Scheffer, M., Elmqvist, T., Gunderson, L., and Holling, C. S.: Regime Shifts, Resilience, and Biodiversity in Ecosystem Management, Annu. Rev. Ecol. Evol. Syst., 35, 557-581, 2004.

Godhe, A., Asplund, M. E., Härnström, K., Saravanan, V., Tyagi, A., and Karunasagar, I.: Quantification of diatom and dinoflagellate biomasses in coastal marine seawater samples by real-time PCR, Appl. Environ. Microbiol., 74, 7174-7182, 2008.

Gray, D., Piprell, C., and Mark, G.: National Parks of Thailand, Industrial Finance Corporation of Thailand, 1991.

Häder, D. P. and Gao, K.: Interactions of anthropogenic stress factors on marine phytoplankton, Front. Environ. Sci., 3, 14, doi:10.3389/fenvs.2015.00014, 2015.

Hallam, S. J., Girguis, P. R., Preston, C. M., Richardson, P. M., and DeLong, E. F.: Identification of Methyl Coenzyme M Reductase A (mcrA) Genes Associated with Methane-Oxidizing Archaea, Appl. Environ. Microbiol., 69, 5483-5491, 2003.

Hallam, S. J., Putnam, N., Preston, C. M., Detter, J. C., Rokhsar, D., Richardson, P. M., and DeLong, E. F.: Reverse Methanogenesis: Testing the Hypothesis with Environmental Genomics, Science, 305, 1457-1462, 2004.

Hou, W., Dong, H., Li, G., Yang, J., Coolen, M. J., Liu, X., Wang, S., Jiang, H., Wu, X., Xiao, H., Lian, B., and Wan, Y.: Identification of photosynthetic plankton communities using sedimentary ancient DNA and their response to late-Holocene climate change on the Tibetan Plateau, Sci. Rep., 4, 6648, doi:10.1038/srep06648, 2014.

Imboden, D. M. and Wüest, A.: Mixing mechanisms in lakes, in: Physics and Chemistry of Lakes, edited by: Lerman, A., Imboden, D., and Gat, J., 83-138, Springer, Berlin, Germany, 1995.

Jungblut, A. D., Allen, M. A., Burns, B. P., and Neilan, B. A.: Lipid biomarker analysis of cyanobacteria-dominated microbial mats in meltwater ponds on the McMurdo Ice Shelf, Antarctica, Org. Geochem., 40, 258-269, 2009.

Kirilova, E. P., Heiri, O., Bluszcz, P., Zolitschka, B., and Lotter, A. F.: Climate-driven shifts in diatom assemblages recorded in annually laminated sediments of Sacrower See (NE Germany), Aquat. Sci., 73, 201-210, 2011.

Konecky, B. L., Russell, J. M., Rodysill, J. R., Vuille, M., Bijaksana, S., and Huang, Y.: Intensification of southwestern Indonesian rainfall over the past millennium, Geophys. Res. Lett., 40, 386-391, 2013.

Kuffner, M., Hai, B., Rattei, T., Melodelima, C., Schloter, M., Zechmeister-Boltenstern, S., Jandl, R., Schindlbacher, A., and Sessits, A.: Effects of season and experimental warming on the bacterial community in a temperate mountain forest soil assessed by $16 \mathrm{~S}$ rRNA gene pyrosequencing, FEMS Microbiol. Ecol., 82, 551-562, 2012.

Landesman, W. J. and Dighton, J.: Response of soil microbial communities and the production of plant-available nitrogen to a twoyear rainfall manipulation in the New Jersey Pinelands, Soil Biol. Biochem., 42, 1751-1758, 2010.
Lee, Z. M.-P., Bussema, C., and Schmidt, T. M.: rrnDB: documenting the number of rRNA and tRNA genes in bacteria and archaea, Nucleic Acids Res., 37, D489-D493, 2009.

Leturque, H. and Wiggins, S.: Thailand's progress in agriculture: Transition and sustained productivity growth, Overseas Development Institute, 11 pp., 2011.

Litke, D. W.: Review of phosphorus control measures in the US and their effects on water quality. National Water Quality Assessment Program: Water-Resources Investigations Report, Report nr, 994007, 1999.

Lotter, A. F. and Birks, H. J. B.: The separation of the influence of nutrients and climate on the varve time-series of Baldeggersee, Switzerland, Aquat. Sci., 59, 362-375, 1997.

Mackay, A. W., Jones, V. J., and Battarbee, R. W.: Approaches to Holocene climate reconstruction using diatoms, in: Global change in the Holocene, edited by: Mackay, A. W., Battarbee, R. W., Birks, H. J. B., and Oldfield, F., Arnold, 294-309, 2003.

Malmqvist, B., Rundle, S. D., Covich, A. P., Hildrew, A. G., Robinson, C. T., and Townsend, C. R.: Prospects for streams and rivers: an ecological perspective, in: Aquatic systems: trends and global perspectives, edited by: Polunin, N., 19-29, Cambridge, UK, Cambridge University Press, 2008.

McKirdy, D. M., Spiro, B., Kim, A. W., Brenchley, A. J., Hepplewhite, C. J. and Mazzoleni, A. G.: Environmental significance of mid- to late Holocene sapropels in Old Man Lake, Coorong coastal plain, South Australia: an isotopic, biomarker and palaeoecological perspective, Org. Geochem., 58, 13-26, 2013.

Metzger, P. and Largeau, C.: Botryococcus braunii: a rich source for hydrocarbons and related ether lipids, Appl. Microbiol. Biotechnol., 66, 486-496, 2005.

Meyers, P. A. and Teranes, J. L.: Sediment organic matter, in: Tracking Environmental Change Using Lake Sediments. Physical and Geochemical Methods, vol. 2., edited by: Last, W. M. and Smol, J., Kluwer Academic Publishers, Dordrecht, 239-268, 2001.

Meyers, P. A.: Applications of organic geochemistry to paleolimnological reconstructions: a summary of examples from the Laurentian Great Lakes, Org. Geochem., 34, 261-289, 2003.

Murphy, A. E., Sageman, B. B., Hollan-Der, D. J., Lyons, T. W., and Brett, C. E.: Black shale deposition and faunal overturn in the Devonian Appalachian basin: Clastic starvation, seasonal watercolumn mixing, and efficient biolimiting nutrient recycling, $\mathrm{Pa}-$ leoceanography, 15, 280-291, 2000.

Niedermeyer, E. M., Sessions, A. L., Feakins, S. J., and Mohtadi, M.: Hydroclimate of the Indo-Pacific Warm Pool during the past 24,000 years, P. Natl. Acad. Sci. USA, 111, 9402-9406, 2014.

Paerl, H. W. and Valerie, J. P.: Climate change: Links to global expansion of harmful Cyanobacteria, Water Res., 46, 1349-1363, 2012.

Paerl, H. W. and Fulton III, R. S.: Ecology of Harmful Cyanobacteria, in: Ecology of Harmful Marine Algae, 95-107 pp., edited by: Graneli, E. and Turner, J., Springer-Verlag, Berlin, 2006.

Prokopowich, C. D., Gregory, T. R., and Crease, T. J.: The correlation between rDNA copy number and genome size in eukaryotes, Genome, 46, 48-50, 2003.

Puri, J.: Factors affecting agricultural expansion in forest reserves of Thailand: the role of population and roads, dissertation submitted to the faculty of the graduate school of the university of Maryland, college park, USA, 2006. 
Ravasi, D. F., Peduzzi, S., Guidi, V., Peduzzi, R., Wirth, S. B., Gilli, A. and Tonolla, M.: Development of a real-time PCR method for the detection of fossil 16S rDNA fragments of phototrophic sulfur bacteria in the sediments of Lake Cadagno, Geobiology, 10, 196-204, 2012.

Robador, A., Müller, A. L., Sawicka, J. E., Berry, D., Hubert, C. R., Loy, A., Jørgensen, B. B., and Brüchert, V.: Activity and community structures of sulfate-reducing microorganisms in polar, temperate and tropical marine sediments, ISME J., 10, 796-809, doi:10.1038/ismej.2015.157, 2016.

Scheffer, M., Carpenter, S., Foley, J. A., Folke, C., and Walker, B.: Catastrophic shifts in ecosystems, Nature, 413, 591-596, 2001.

Schirrmeister, B., Dalquen, D., Anisimova, M., and Bagheri, H.: Gene copy number variation and its significance in cyanobacterial phylogeny, BMC Microbiology, 12, 177, doi:10.1186/14712180-12-177, 2012.

Sessions, A. L., Burgoyne, T. W., Schimmelmann, A., and Hayes, J. M.: Fractionation of hydrogen isotopes in lipid biosynthesis, Org. Geochem., 30, 1193-1200, 1999.

Sessions, A. L., Burgoyne, T. W., and Hayes, J. M.: Correction of $\mathrm{H} 3+$ contributions in hydrogen isotope ratio monitoring mass spectrometry, Anal. Chem., 7, 192-199, 2001.

Smittenberg, R. H., Baas, M., Schouten, S., and Sinninghe Damsté, J. S.: The demise of the alga Botryococcus braunii from a Norwegian fjord was due to early eutrophication, The Holocene, 15, 133-140, 2005.

Snansieng, S., Gitisan, N., and Sripongpan, P.: Geological map of Changwat Nakhon Si Thammarat. NC47-15, GeolSurv Div, Dept Mineral Res, Thailand, 1976.

Souza, M. B. G., Barros, C. F. A., Barbosa, F., Hajnal, E., and Padisak, J.: Role of atelomixis in replacement of phytoplankton assemblages in Dom Helvécio Lake, South-East Brazil, Hydrobiologia, 607, 211-224, 2008.

Sun, M. Y., Zou, L., Dai, J., Ding, H., Culp, R. A. and Scranton, M. I.: Molecular carbon isotopic fractionation of algal lipids during decomposition in natural oxic and anoxic seawaters, Org. Geochem., 35, 895-908, 2004.

Sylvan, J. B., Sia, T. Y., Haddad, A. G., Briscoe, L. J., Toner, B. M., Girguis, P. R., and Edwards, K. J.: Low temperature geomicrobiology follows host rock composition along a geochemical gradient in Lau Basin, Front Microbiol., 4, 61, doi:10.3389/fmicb.2013.00061, 2013.

Takai, K. and Horikoshi, K.: Rapid detection and quantification of members of the archaeal community by quantitative PCR by using fluorogenic probes, Appl. Environ. Microbiol., 66, 50665072, 2000.

Tsai, Y.-L. and Olson, B. H.: Rapid method for direct extraction of DNA from soils and sediments, Appl. Environ. Microbiol., 54, 1070-1074, 1991.
Vahtera, E., Conley, D. J., Gustafsson, B. G., Kuosa, H., Pitkanen, H., Savchuk, O. P., Tamminen, T., Viitasalo, M., Voss, M., Wasmund, N., and Wulff, F.: Internal ecosystem feedbacks enhance nitrogen-fixing cyanobacteria blooms and complicate management in the Baltic Sea, Royal Swedish Academy of Sciences, Ambio, 36, 2-3, 2007.

Wada, E.: Nitrogen isotope fractionation and its significance in biogeochemical processes occurring in marine environments, in: Isotope Marine Chemistry, edited by: Goldberg, E., Horibe, Y., and Saruhashi, K., 375-398, 1980.

Waldmann, N., Borromei, A. M., Recasens, C., Olivera, D., Martínez, M. A., Maidana, N. I., Ariztegui, D., Austin, Jr. J. A., Anselmetti, F. S., and Moy, C. M.: Integrated reconstruction of Holocene millennial-scale environmental changes in Tierra del Fuego, southernmost South America, Palaeogeogr. Palaeocl., 399, 294-309, 2014.

Wennrich, V., Minyuk, P. S., Borkhodoev, V., Francke, A., Ritter, B., Nowaczyk, N. R., Sauerbrey, M. A., Brigham-Grette, J., and Melles, M.: Pliocene to Pleistocene climate and environmental history of Lake El'gygytgyn, Far East Russian Arctic, based on high-resolution inorganic geochemistry data, Clim. Past, 10, 1381-1399, doi:10.5194/cp-10-1381-2014, 2014.

Woodward, G., Perkins, D. M., and Brown, L. E.: Climate change and freshwater ecosystems: impacts across multiple levels of organization, Phil. Trans. R. Soc. B., 365, 2093-2106, 2010.

Yamoah, K. K., Chabangborn, A., Chawchai, S., Väliranta, M., Wohlfarth, B., and Smittenberg, R. H.: Large variability in $n$ alkane $\delta^{13} \mathrm{C}$ values in Lake Pa Kho (Thailand) driven by wetland wetness and aquatic productivity, Org. Geochem., 97, 5360, 2016.

Yin, D. C., Zheng, L. L., and Song, L. R.: Spatiotemporal distribution of phytoplankton in the Dan jiangkou Reservoir, a water source area for the South-to-North Water Diversion Project (Middle Route), China, Chin. J. Oceanol. Limnol., 29, 531-540, 2011.

Young, H. S., Mccauley, D. J., Dunbar, R. B., Hutson, M. S., TerKuile, A. M., and Dirzo, R.: The roles of productivity and ecosystem size in determining food chain length in tropical terrestrial ecosystems, Ecology, 94, 692-701, 2013.

Zeglin, L. H., Bottomley, P. J., Jumpponen, A., Rice, C. W., Arango, M., Lindsley, A., McGowan, A., Mfombep, P. and Myrold, D. D.: Altered precipitation regime affects the function and composition of soil microbial communities on multiple time scales, Ecology, 94, 2334-2345, 2013.

Zhu, F., Massana, R., Not, F., Marie, D., and Vaulot, D.: Mapping of picoeucaryotes in marine ecosystems with quantitative PCR of the 18S rRNA gene, FEMS Microbiol. Ecol., 52, 79-92, 2005.

Zimmerman, A. R. and Canuel, E. A.: A geochemical record of eutrophication and anoxia in Chesapeake Bay sediments: anthropogenic influence on organic matter composition, Mar Chem., 69, 117-137, 2000. 